\title{
REVISÃO DOS GÊNEROS PSEUDESTOLA BREUNING, ESTOLOMIMUS BREUNING E EUESTOLA BREUNING (COLEOPTERA, CERAMBYCIDAE, LAMIINAE, DEMIPHORINI)
}

\author{
Ubirajara R. Martins ${ }^{1}$ \\ Maria Helena M. Galileo ${ }^{2}$
}

\begin{abstract}
Revision of the genera Pseudestola Breuning, Estolomimus Breuning and Euestola Breuning (Coleoptera, Cerambycidae, Laminae, DemiphorlNI). The genera Pseudestola, Estolomimus and Euestola are revised and keyed. Neoestola Breuning, 1940 is considered a synonym of Estolomimus Breuning, 1940. Estola curta Breuning, 1940 is transferred to Estolomimus and redescribed. New species described from Brazil: Estolomimus apicale sp.n. (Espírito Santo), E. distinctus sp.n. (Espírito Santo), E. pulvereus sp.n. (Santa Catarina); Euestola fasciata sp.n. (São Paulo to Santa Catariana), E. basalis sp.n. (Minas Gerais), E. lineata sp.n. (Espírito Santo). Redescriptions and additional records are provided for: Pseudestola densepunctata Breuning, 1940, Estolomimus solidus (Breuning, 1940), E. marmoratus Breuning, 1940 and Euestola basidensepunctata Breuning, 1943.

KEY WORDS. Cerambycidae, Desmiphorini, Estomolomimus, Euestola, Pseudestola, Neotropical
\end{abstract}

Os gêneros de Desmiphorini com espinho ou espículo nos lados do protórax foram divididos por BREUNING (1974) em dois agrupamentos: (1) mesotíbias recortadas ("échancrés"), (2) mesotíbias com sulco raso ("pourvus que d'un léger sillon dorsal"), caráter de difícil avaliação. Parte dos gêneros do primeiro agrupamento, isto é, os que envolvem espécies com cabeça retrátil e antenas desprovidas de pêlos no lado interno dos flagelômeros basais, é o objeto desta contribuição: Estolomimus Breuning, 1940; Euestola Breuning, 1943; Pseudestola Breuning, 1940 e Neoestola Breuning, 1940. Este último é considerado sinônimo de Estolomimus; os outros são redefinidos com base em novos caracteres.

Referências bibliográficas sob cada táxon restringem-se à descrição original e ao catálogo de MONNÉ (1994) onde as referências estão completas.

Abreviaturas citadas no texto correspondem a: $\mathrm{BMNH}$ - The Natural History Museum, Londres; CMNH - Carnegie Museum of Natural History, Pittsburgh; MCNZ - Museu de Ciências Naturais, Fundação Zoobotânica do Rio Grande do Sul, Porto Alegre; MNRJ - Museu Nacional, Universidade Federal do Rio de Janeiro, Rio de Janeiro; MZSP - Museu de Zoologia, Universidade de São Paulo, São Paulo.

1) Museu de Zoologia, Universidade de São Paulo. Caixa Postal 7172, 01064-970 São Paulo, São Paulo, Brasil. Pesquisador CNPq.

2) Museu de Ciências Naturais, Fundação Zoobotânica do Rio Grande do Sul. Caixa Postal 1188, 90001-970 Porto Alegre, Rio Grande do Sul, Brasil. Pesquisador CNPq. 
Chave para os gêneros de Desmiphorini com mesotíbias profundamente sulcadas, cabeça retrátil e flagelômeros sem franja de pêlos

1. Todo corpo e apêndices desprovidos de setas; espículo lateral do protórax situado ao nível do terço basal; élitros densa e uniformemente pontuados em toda a

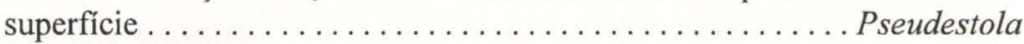

- Élitros, fêmures e tíbias (50X) com setas curtas, duras, truncadas na extremidade; espículo lateral do protórax situado próximo ao meio; pontuação elitral desuniforme . . . . . . . . . . . . . . . . . . . . . . . . 2

2(1). Setas da metade anterior dos élitros implantadas em tubérculos; aspecto geral robusto ................................. Estolomimus

- Setas da metade anterior dos élitros implantadas em pontos; aspecto geral subalongado .............................. Euestola

\section{Estolomimus Breuning, 1940}

Estolomimus Breuning, 1940: 181. - Monné, 1994: 51

Neoestola Breuning, 1940: 182. Syn.n.

Espécie-tipo de Estolomimus, E. marmoratus Breuning, 1940 (monotipia); de Neoestola, N. solida Breuning, 1940 (monotipia).

Aspecto geral compacto. Fronte nitidamente mais larga que longa. Olhos grosseiramente facetados. Lobos oculares inferiores pequenos, pouco mais longos do que as genas; lobos oculares superiores com 5-6 fileiras de omatídios, mais desenvolvidos nos machos do que nas fêmeas, mais distantes entre si do que a largura de um lobo. Antenas (macho) aproximadamente tão longas quanto o corpo; (fêmea) atingem a declividade apical. Escapo subcilíndrico; tão longo quanto o antenômero III. Antenômero III sem franja de pêlos no lado inferior e pouco mais curto do que o IV; antenômeros V-XI com comprimentos subiguais. Flagelômeros IV a XI com tegumento bicolor. Protórax mais largo do que longo com espículo lateral, acuminado, situado geralmente um pouco atrás do meio. Pronoto convexo, sem gibosidades, com depressão transversal à frente do escutelo, densamente pontuado em toda a superfície. Prosterno muito curto; processo prosternal regularmente curvo mais estreito do que a procoxa. Cavidades coxais anteriores angulosas nos lados; cavidades coxais intermediárias fechadas. Mesosterno transversalmente aprofundado; processo mesosternal com lados convergentes, sem tubérculo. Lados do metasterno e dos urosternitos densa e profundamente pontuados. Élitros com gibosidade centro-basal discreta; na base, sensivelmente mais largos do que o protórax; margens laterais subparalelas e, no terço apical, arredondadas; extremidades desarmadas arredondadas em conjunto. Pontuação elitral densa e profunda na metade anterior; setas curtas grosseiras, truncadas no ápice e inseridas sobre tubérculos. Fêmures pedunculados e clavados, com pontos contrastantes e setas curtas, duras e truncadas na extremidade. Tíbias com o mesmo tipo de setas; mesotíbias com sulco profundo no terço apical. Metatarsômero I mais curto do que o comprimento do II e III em conjunto. 


\section{Estolomimus apicale sp.n.}

Fig. 1

Tegumento castanho-escuro, mais avermelhado no terço apical dos élitros. Tíbias com anel central de tegumento amarelo-avermelhado. Antenas castanhas com tegumento amarelado em: terço basal dos antenômeros III, IV e VI, base dos antenômeros V, VII e IX, dois terços basais dos antenômeros VIII e X, e metade basal do XI. Fronte com pontuação fina e densa; duas máculas de pubescência amarelada situadas ao lado da sutura frontal, na base dos tubérculos anteníferos. Lobos oculares inferiores com mais do que o dobro do comprimento das genas; lobos oculares superiores com 6 fileiras de omatídios; nos machos, apenas mais distantes entre si do que a largura de um lobo; nas fêmeas, tão distantes entre si quanto quase o dobro da largura de um lobo. Escapo $(50 \mathrm{x})$ muito fina e densamente pontuado. Antenômero III apenas mais curto do que o IV. Espinho lateral do protórax situado pouco atrás do meio. Pronoto marmorado de amarelado mais evidente no disco e junto aos espículos laterais. Escutelo bordejado por pubescência amarelada. Élitros com os dois terços anteriores castanho-escuros, profundamente pontuados, com cerdas pretas, curtas, truncadas no ápice e inseridas sobre tubérculos; terço apical revestido por pubescência escamiforme, esbranquiçada, com setas não inseridas em tubérculos projetados; limite entre as duas colorações elitrais transversal. Em alguns exemplares, a região castanha junto à sutura apresenta alguma pubescência amarelada. Gibosidade centro-basal dos élitros discreta. Face ventral densamente pontuada. Prosterno, lados do metasterno e dos urosternitos variegados de pubescência amarelada. Fêmures com pubescência amarelada e pontos contrastantes. Fêmures e tíbias com pêlos curtos, esbranquiçados, truncados no ápice.

Dimensões em milímetros, macho/fêmea. Comprimento total, 4,4-4,6/5,96,8 ; comprimento do protórax, 1,0-1,1/1,3-1,5; maior largura do protórax, 1,41,5/1,8-2,2; comprimento do élitro, 3,1-3,3/4,3-4,9; largura umeral, 1,7-1.8/2,4-2,8.

Material-tipo. Holótipo fêmea. BRASIL, Espírito Santo: Linhares, X.1972, P.C. Elias leg. (MZSP). Parátipos: 2 macho, 1 fêmea, mesmos dados do holótipo (MZSP).

Discussão. Estolomimus apicale caracteriza-se, dentre as espécies com metatíbias bicolores, pelo terço apical dos élitros recoberto por pubescência amarelo-esbranquiçada uniforme.

\section{Estolomimus distinctus sp.n.}

Fig. 2

Fêmea. Tegumento castanho-escuro a preto; metatíbias com anel central de tegumento amarelo-avermelhado. Fronte fina e densamente pontuada; região centro-superior com duas máculas de pubescência amarelada. Antenas castanhas com tegumento amarelo-avermelhado em: base de III, V, VII e IX; terço basal deIV, VI, VIII e X; inteiramente em XI exceto extremo apical. Lobos oculares inferiores pouco mais longos do que as genas; lobos superiores com cinco fileiras de omatí- 


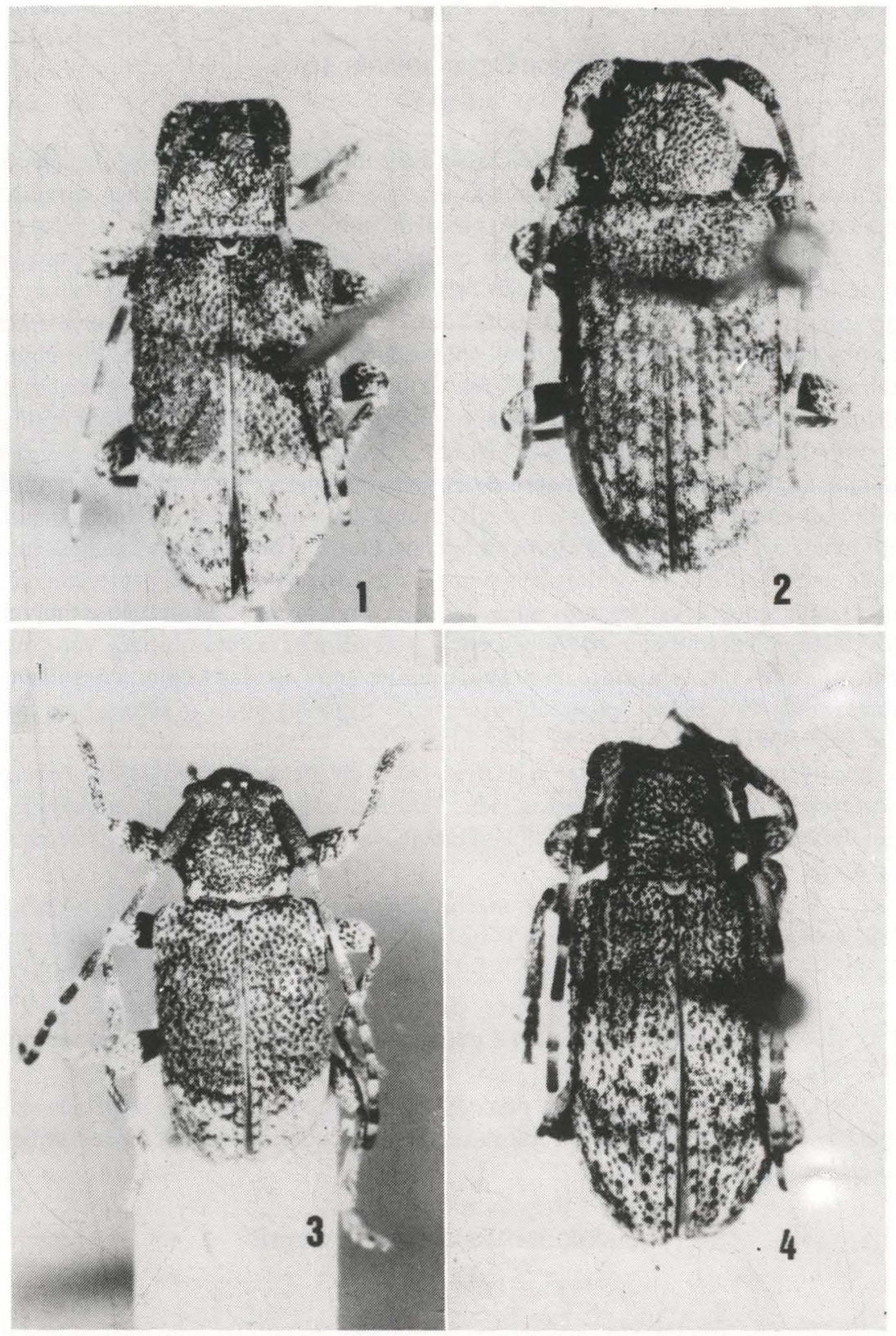

Figs 1-4. Estolominus apicale sp.n., holótipo fêmea, comprimento, 5,9 mm; (2) E. distinctus sp.n., holótipo fêmea, comprimento, $5,5 \mathrm{~mm}$; (3) E. solidus (Breuning, 1940), fêmea de (Nova Teutônia), Seara, Santa Catarina; (4) E. curtus (Breuning, 1940), fêmea de Linhares, Espírito Santo. 
dios, tão distantes entre si quanto quase o dobro da largura de um lobo. Antenas atingem o terco apical dos élitros. Escapo (50x) microesculturado, pontuado, marmorado com pubescência amarelada e com alguns pêlos brancos, duros, truncados no ápice. Antenômeros III e IV com comprimentos subiguais. Espinho lateral do protórax situado pouco atrás do meio. Pronoto densamente pontuado, marmorado de pubescência amarelada, mais concentrada em duas máculas nos lados da base. Escutelo bordejado por pubescência esbranquiçada. Élitros com pubescência amarelo-alaranjada: faixa estreita, transversal, junto à base; em manchas subcirculares, próximas, que constituem uma faixa irregular ao nível do terço anterior; no terço apical em máculas e áreas pouco maiores. Gibosidade basal dos élitros discreta; pêlos curtos da metade basal inseridos em tubérculos; pontos do dorso na região central organizados em fileiras longitudinais. Face ventral densamente pontuada; lados do metasterno e dos uroternitos marmorados de pubescência amarelo-alaranjada. Metade apical dos fêmures com pubescência amarelo-alaranjada, densamente marmorada de pontos escuros. Fêmures e tíbias com alguns pêlos brancos, duros, truncados no ápice.

Dimensões em milímetros. Comprimento total, 6,3; comprimento do protórax, 1,4; maior largura do protórax, 2,0; comprimento do élitro, 4,5; largura umeral, 2,7 .

Material-tipo. Holótipo fêmea. BRASIL, Espírito Santo: Linhares (Parque Sooretama), 17-27.X.1978, F.S. Pereira leg. (MZSP).

Discussão. Estolomimus distinctus é muito semelhante a E. marmoratus que examinamos através do diapositivo do holótipo feito por J.S. Moure no BMNH; nesta espécie, contudo, os pontos do meio do dorso dos élitros não são alinhados e as metatíbias são escuras, unicolores.

$E$. distinctus distingue-se de $E$. apicale pelo padrão de colorido e pelos pontos dorsais dos élitros alinhados.

\section{Estolomimus solidus (Breuning, 1940), comb.n.}

\section{Fig. 3}

Neostola solida Breuning, 1940: 183. - Monné, 1994: 52 (cat.).

Tegumento castanho-avermelhado; meso- e metatíbias com anel central de tegumento amarelado; tarsômeros alaranjados. Fronte como em E. distinctus, também dotada de duas máculas centrais de pubescência amarelo-alaranjada. Antenas (macho) tão longas quanto o corpo, castanhas, tegumento branco-amarelado em: base de III, V e VII; metade basal em IV, VI, VIII, X; inteiramente em IX e na metade apical de XI. Escapo como em E. distinctus. Antenômero III aproximadamente tão longo quanto o escapo e nitidamente mais curto do que o IV. Pronoto marmorado com alguma pubescência amarelo-alaranjada, mais concentrada em duas máculas laterais, uma na base, outra pouco adiante. Espinho lateral do protórax situado pouco atrás do nível do meio. Escutelo com pubescência esbranquiçada mais densa nas bordas. Élitros com pubescência amarelo-alaranjada mais densa junto à base e no terço apical; restante da superfície com marmorado amarelado mais esparso. Pontos da região centro-dorsal não organizados em fileiras longitudinais; gibosidade centro-basal discreta. Face ventral e pernas como em E. distinctus. 
Dimensões em milímetros. Comprimento total, 4,1-5,5; comprimento do protórax, 1,0-1,9; maior largura do protórax, 1,3-1,8; comprimento do élitro, 2,9-3,9; largura umeral, 1,7-2,4.

Material examinado. BrasiL, São Paulo: Monte Alegre (Fazenda Santa Maria, 1100 m), macho, 24-30.XI.1942, F. Lane leg. (MZSP); Santa Catarina: Seara (Nova Teutônia), macho, X.1965, F. Plaumann leg. (MZSP).

Discussão. O exemplar de Nova Teutônia é maior e a região elitral, entre as áreas densas de pubescência amarelo-alaranjada, quase não apresenta marmorado de pubescência amarelada.

E. solidus, pelo padrão de colorido assemelha-se mais a $E$. distinctus, mas separa-se pelo antenômero III mais curto do que o IV e pelos pontos da região centro-dorsal dos élitros não organizados em fileiras.

\section{Estolomimus curtus (Breuning, 1940), comb.n.}

Fig. 4

Estola curta Breuning, 1940: 182. - Monné, 1994: 44 (cat.).

Tegumento castanho-avermelhado mais escuro na cabeça e no protórax. Tíbias com tegumento avermelhado, uniforme. Cabeça densamente marmorada de pubescência branco-amarelada. Fronte sem máculas centro-superiores. Lobos oculares inferiores estreitos, pouco mais longos do que as genas; lobos superiores com 5-6 fileiras de omatídios, aproximadamente tão distantes entre si quanto a largura de um lobo (fêmea). Antenas atingem as extremidades elitrais. Escapo marmorado de pubescência esbranquiçada, com algumas setas brancas, duras, truncadas no ápice. Flagelômeros castanhos, com tegumente branco-amarelado em: metade basal do IV; bases de V, VII e IX; inteiramente, exceto extremo apical em VI, VIII, X e XI. Espinho lateral do protórax situado ao nível do meio. Pronoto densamente pontuado, marmorado de pubescência amarelada, sem manchas de pubescência mais concentrada na base. Escutelo com pubescência amarelada. Élitros com a metade basal revestida por pubescência escamiforme amarelada; região central com faixa transversal de pubescência branca; metade apical predominantemente branca com duas faixas oblíquas, indistintas de pubescência mais amarelada. Gibosidades centro-basais discretas. Setas elitrais da metade anterior inseridas em tubérculos bem evidentes. Pontos dorsais sobre a faixa branca não alinhados. Face inferior e pernas densamente marmoradas de castanho. Fêmures e tíbias com setas duras, esbranquiçadas, truncadas no ápice.

Variabilidade. Nos exemplares do Rio Grande do Sul a metade apical dos élitros tem pubescência quase uniforme, não nitidamente interrompida por faixas oblíquas mais amareladas.

Dimensões em milímetros. Comprimento total, 5,7-6,4; comprimento do protórax, 1,2-1,4; maior largura do protórax, 1,6-1,9; comprimento do élitro, 4,0-4,6; largura umeral, 2,2-2,5.

Material examinado. BRAsIL, Espírito Santo: Linhares, 2 fêmeas, X.1972, P.C. Elias leg. (MZSP); Santa Catarina: Seara (Nova Teutônia), fêmea, 27.I.1929, 
F. Plaumann leg. (MZSP); Rio Grande do Sul: Arroio do Meio (Linha Alegre), macho, 8.I.1975, A. Lise leg. (MCNZ); São Jerônimo, macho, 19.X.1982, E.H. Buckup leg. (MCNZ).

Discussão. Esta espécie insere-se em Estolomimus muito mais apropriadamente do que em Estola pelo aspecto geral compacto, flagelômeros basais desprovidos de pêlos no lado interno, presença de pêlos elitrais da metade anterior implantados em tubérculos, élitros com pubescência de aspecto escamiforme e setas curtas, com aspecto grosseiro.

Estolomimus curtus distingue-se das outras espécies com tíbias unicolores pelo antenômero III unicolor e pela presença de faixa transversal de pubescência branca no meio dos élitros.

\section{Estolomimus marmoratus Breuning, 1940}

Estolomimus marmoratus Breuning, 1940: 181. - Monné, 1994: 51 (cat.).

Examinada através do diapositivo do holótipo fotografado por J.S. Moure no BMNH. Metatíbias unicolores, sem anel central de tegumento amarelo-esbranquiçado. Os élitros não apresentam a região basal com pubescência acinzentada ou amarelada; no terço anterior o marmorado é mais esparso e na metade apical bem manifesto, mas não chega a constituir máculas definidas como ocorre em $E$. pulvereus sp.n. Os tubérculos da metade basal onde se inserem as setas são bem evidentes.

Originalmente descrita do Ceará, o holótipo mede 4,75 mm de comprimento por $2 \mathrm{~mm}$ de largura umeral (BREUNING 1974).

\section{Estolomimus pulvereus sp.n.}

Tegumento preto ou castanho-avermelhado escuro. Tíbias com tegumento uniforme sem anel central de tegumento esbranquiçado. Fronte densamente pontuada com pubescência alaranjada esparsa e concentrada em duas máculas centrais na metade superior. Lobos oculares inferiores pouco mais longos do que as genas; lobos oculares superiores com 5 fileiras de omatídios, mais distantes entre si do que a largura de um lobo (fêmea). Antenas (fêmea) atingem a declividade apical. Escapo castanho com algumas setas, brancas, truncadas na extremidade. Flagelômeros castanhos com tegumento branco-amarelado em: base de III, V, VII, IX e XI, terço basal de IV, VI, VIII e X. Espinho lateral do protórax situado pouco atrás do meio. Pronoto densamente pontuado, esparsamente marmorado de pubescência alaranjada que está mais concentrada em duas máculas nos lados da base. Escutelo com pubescência branco-amarelada mais concentrada nas bordas. Élitros com pubescência alaranjada mais concentrada na base e em pequenas manchas em todo o terço apical; gibosidades centro-basais discretas; pontos da região centro-dorsal não alinhados. Face inferior densamente pontuada. Metade apical dos fêmures amarelo-alaranjada salpicada de pontos escuros. Fêmures e tíbias com setas, brancas, duras, truncadas no ápice. 
Dimensões em milímetros. Comprimento total, 6,0-6,3; comprimento do protórax, 1,2-1,5; maior largura do protórax, 1,7-2,0; comprimento do élitro, 4,3-4,4; largura umeral, 2,3-2,7.

Material-tipo. Holótipo fềmea. BRASIL, Santa Catarina: Seara (Nova Teutônia), XII.1976, F. Plaumann leg. (MZSP). Parátipos. Santa Catarina: Ilha do Arvoredo, fêmea, 13-14.X.1994, A. Franceschini leg. (MCNZ); Rancho Queimado, fêmea, 12-15.I.1995, A. Bonaldo leg. (MCNZ); macho, 15-18.XI.1995, L. Moura leg. (MCNZ); São Bento do Sul (Rio Vermelho), fêmea, X.1952, Dirings leg. (MZSP).

Discussão. E. pulverus distingue-se de E. marmoratus pela pubescência alaranjada da metade apical dos élitros distribuída em manchas pequenas e mais ou menos individualizadas, não ou apenas coalescentes. Além disso, a distribuição geográfica das duas espécies é bastante diversa.

\section{Chave para as espécies do gênero Estolomimus}

1. Metatíbias unicolores, com tegumento escuro $\ldots \ldots \ldots \ldots \ldots \ldots \ldots \ldots \ldots \ldots$

- Metatíbias com anel central de tegumento branco-amarelado . . . . . . . . . 4 2(1). Antenômero III unicolor com tegumento escuro; élitros com faixa de pubescência esbranquiçada, transversal, ao nível do meio. Brasil (Espírito Santo ao Rio Grande do Sul $\ldots . \ldots \ldots \ldots \ldots \ldots \ldots \ldots \ldots$. curtus

- Antenômero III com região basal anelada por tegumento branco-amarelado; élitros sem faixa de pubescência esbranquiçada ao nível do meio . . . . . 3 3

3(2). Metade apical dos élitros salpicada de máculas de pubescência alaranjada; anel basal do antenômero III com tegumento branco. Brasil (Santa Catarina) ... . .pulvereus

- Metade apical dos élitros marmorada por pubescência amarelada; terço basal do antenômero III com tegumento alaranjado. Brasil (Ceará) . . . . marmoratus

4(1). Terço apical dos élitros com pubescência amarelo-esbranquiçada, uniforme, separada dos dois terços anteriores castanhos por linha transversal; região basal dos élitros sem faixa transversal de pubescência amarelada mais densa. Brasil (Espírito Santo) .......................... apicale

- Terço apical dos élitros marmorado de pubescência amarelo-alaranjada, quando mais compacta, separada da parte escura por linha obliqua; base dos élitros com faixa de pubescência . ........................ 5

5(4). Região centro-dorsal dos élitros com pontos organizados em fileiras longitudinais. Brasil (Espírito Santo )..................... distinctus

- Região centro-dorsal dos élitros com pontos não organizados em fileiras longitudinais. Brasil (Rio de Janeiro a Santa Catarina) . . . . . . . . . solidus 


\section{Euestola Breuning, 1943}

Euestola Breuning, 1943: 54. - Monné, 1994: 51 (cat.).

Espécie-tipo, Euestola basidensepunctata Breuning, 1943 (monotipia).

Aspecto geral subalongado. Fronte mais larga do que longa. Olhos grosseiramente facetados. Lobos oculares inferiores estreitos, pouco mais longos do que as genas; lobos oculares superiores com 5 fileiras de omatídios, tão distantes entre si quanto o dobro da largura de um lobo. Antenas (macho) com comprimento subigual ao do corpo; (fêmea) atingem o quinto apical dos élitros. Escapo subcilíndrico tão longo quanto o antenômero III. Antenômero III sem franja de pêlos no lado inferior, pouco mais curto ou apenas mais longo do que o IV. Antenômeros V - XI com comprimentos subiguais ou ligeiramente decrescentes para o ápice. Protórax mais largo do que longo, com espículo lateral acuminado, situado pouco atrás do meio. Pronoto convexo, transversalmente deprimido junto à base; densamente pontuado em toda a superfície. Prosterno muito curto; processo prosternal regularmente curvo, mais estreito do que uma procoxa. Cavidade coxal anterior angulosa nos lados; cavidade coxal intermediária fechada. Mesosterno transversalmente aprofundado; processo mesosternal com lados convergentes, sem tubérculo. Lados do metasterno e dos urosternitos pontuados. Élitros com escultura basal variada; setas elitrais implantadas em pontos, curtas, rijas e truncadas no ápice (50x); extremidades elitrais arredondadas. Fêmures pedunculados e clavados, com pontos contrastantes. Tíbias intermediárias com sulco profundo no terço apical. Metatarsômero V mais curto do que I a III.

\section{Euestola basidensepunctata Breuning, 1943}

Fig. 5

Euestola basidensepunctata Breuning, 1943: 55. - Monné, 1994: 51 (cat.).

Tegumento castanho-escuro, mais avermelhado na metade apical dos élitros. Cabeça revestida por densa pubescência escamiforme (50X), branco-amarelada, entremeada por pequenos pontos contrastantes, principalmente no vértice. Fronte subquadrangular. Lobos oculares inferiores estreitos, com aproximadamente o dobro do comprimento das genas; lobos oculares superiores com 5 fileiras de omatídios, tão distantes entre si quanto o dobro da largura de um lobo (fêmea). Antenas atingem o terço apical dos élitros. Escapo robusto, subcilíndrico, revestido por pubescência igual a da cabeça. Antenômero III com tegumento escuro; os dois terços basais revestidos com pubescência igual a da cabeça; flagelômeros seguintes castanhos com tegumento branco-amarelado em: metade basal do IV, dois terços apicais de VI, VIII e X. Protórax mais largo do que longo; espículo lateral localizado atrás do meio. Pronoto com nítida gibosidade centro-basal; pubescência como a da cabeça, não reveste área triangular dorsal da gibosidade à margem basal; duas áreas látero-anteriores sem pubescência amarelada. Escutelo revestido por pubescência amarelada, grosseira. Quarto basal dos élitros muito densa e muito profundamente pontuado, quase sem pubescência; gibosidade centro-basal discreta; restante da superfície elitral revestida por pubescência branco-amarelada esparsamente entre- 


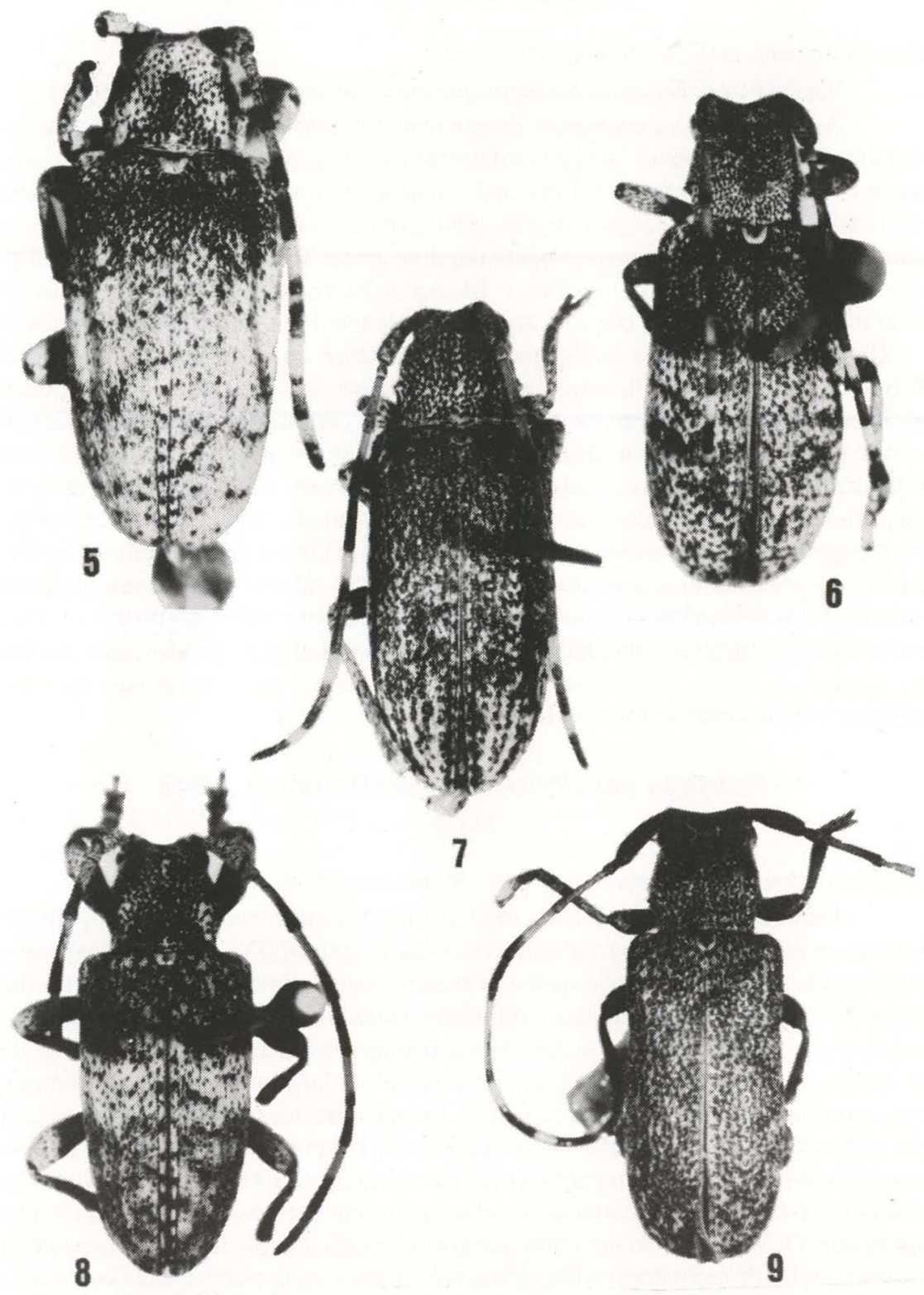

Figs 5-9. (5) Euestola basidensepunctata Breuning, 1943, fêmea de Três Lagoas, Mato Grosso do Sul; (6) $E$. basalis sp.n., holótipo fêmea, comprimento $6,4 \mathrm{~mm}$; (7) $E$. lineata sp.n., holótipo fêmea, comprimento, $7,8 \mathrm{~mm}$; (8) E. fasciata sp.n., holótipo macho, comprimento, $7,0 \mathrm{~mm}$; (9) Pseudestola densepunctata Breuning, 1940, fêmea de Rio de Janeiro, Rio de Janeiro. 
meada por pontos contrastantes, exceto numa faixa de pubescência branca, oblíqua, lateral ao nível do meio; região látero-dorsal ao nível do meio longitudinalmente depremida; setas elitrais curtas, grosseiras, truncadas no ápice. Face ventral e pernas revestidas por pubescência branco-amarelada com alguns pontos contrastantes.

Dimensões em milímetros, Comprimento total, 5,7 ; comprimento do protórax, 1,2; maior largura do protórax, 1,6; comprimento do élitro, 4,4; largura umeral, 2,1 .

Material examinado. BrasiL, Mato Grosso do Sul: Três Lagoas (Fazenda Retiro de Telhas), fêmea, X.1964, Exp. Dep. Zool. leg. (MZSP).

\section{Euestola fasciata sp.n.}

Fig. 8

Tegumento castanho-avermelhado a avermelhado. Cabeça revestida por pubescência branco-amarelada com aspecto escamiforme (50x) salpicada de pequenos pontos contrastantes. Antenômero III com tegumento castanho, metade basal revestida por pubescência branco-amarelada. Flagelômeros V a XI com tegumento castanho; tegumento branco a alaranjado na base de V e VII e inteiramente, exceto o extremo apical, em VI, VIII e X. Espículo lateral do protórax situado pouco atrás do meio. Pronoto regularmente convexo, transversalmente deprimido junto à base; densamente pontuado com pubescência amarelo-esbranquiçada exceto sobre a depressão basal. Élitros com crista centro-basal evidente, aplanados no dorso entre as cristas; região látero-dorsal do meio dos élitros com depressão discreta; terço anterior profunda e densamente pontuado, mas os pontos não contíguos, com intervalos revestidos por pubesência amarelada; região centro-lateral com faixa de pubescência branca, levemente oblíqua em sentido descendente da margem para a sutura que, geralmente, não chega a alcançar. Metade apical dos élitros revestida por pubescência amarelada com alguns pontos contrastantes. Face ventral e pernas revestidas por pubescência amarelada salpicada de pontos contrastantes acastanhados.

Dimensões em milímetros, macho/fêmea. Comprimento total, 6,1-7,0/6,38,4; comprimento do protórax, 1,4-1,5/1,4-1,8; maior largura do protórax, 1,72,0/1,8-2,4; comprimento do élitro, 4,3-4,2/4,6-6,5; largura umeral, 2,4-2,8/2,5-3,3.

Material-tipo. Holótipo macho. BrasIL, São Paulo: Monte Alegre (Fazenda Santa Maria, 1100m), 24-30.XI.1942, F. Lane leg. (MZSP). Parátipos: macho, 2 fêmeas, mesmos dados do holótipo (MZSP); Amparo, macho, fêmea, (MCNZ, MNRJ); Indiana, fêmea, XII.1950, Dirings leg. (MZSP); Paraná: Rondon (24³8'S, $54^{\circ} 7^{\prime}$ W, 500m), macho, X.1952, F. Plaumann leg. (MZSP); Santa Catarina: Timbó, fêmea, XII.1952, Dirings (MZSP).

Discussão. O padrão de colorido de E. fasciata é semelhante ao de $E$. basidensepunctata. Difere: espinho lateral do protórax situado perto do meio; centro do pronoto sem gibosidade; presença de crista centro basal dos élitros; pontuação do terço basal mais esparsa, entremeada por pubescência esbranquiçada e depressão centro-lateral dos élitros mais rasa. 


\section{Euestola basalis sp.n.}

Fig. 6

Tegumento castanho-avermelhado escuro, mais avermelhado nos élitros e nas pernas. Cabeça revestida por pubescência amarelada densa, entremeada por pontos finos contrastantes (os pêlos grossos mas não escamiformes). Lobos oculares inferiores com o triplo do comprimento das genas; lobos superiores com cinco fileiras de omatídios, mais distantes entre si do que a largura de um lobo. Antenas não ultrapassam as extremidades dos élitros nos dois sexos. Escapo subcilíndrico, fina e densamente pontuado. Escapo, pedicelo, antenômero III e metade basal do IV revestidos por pubescência esbranquiçada. Flagelômeros seguintes castanhos, com as seguintes regiões de tegumento amarelado: metade basal do IV, dois terços basais de VI, VIII e X; extremidade de XI. Espículo lateral do protórax situado logo atrás do meio. Pronoto sem gibosidade, convexo; área basal transversalmente deprimida; pontuação grossa e densa entremeada por pubescência amarelada, mais concentrada nos lados. Bordas do escutelo com pubescência amarelada densa. Élitros sem crista centro-basal, com leve gibosidade no dorso da base; pontuação muito densa, grossa, mais concentrada no terço basal onde a pubescência pode estar muito escassa ou entre os pontos; dois terços apicais revestidos por pubescência amarelada mais concentrada em áreas irregulares. Face ventral e pernas recobertas por pubescência amarelada salpicada de pontos escuros, exceto região central do metasterno onde a pubescência é mais rala. Metatarsômero $\mathrm{V}$ mais longo que o I.

Dimensões em milímetros. Comprimento total, 5,5- 6,4; comprimento do protórax, 1,2- 1,3; maior largura do protórax, 1,4-1,7; comprimento do élitro, 3,94,7; largura umeral, 1,9-2,4.

Material-tipo. Holótipo fêmea. BRASIL, Minas Gerais: Santa Bárbara (Serra do Caraça), 23-25.XI.1960, Araújo \& Martins leg. (MZSP). Parátipo macho. Minas Gerais: Viçosa, H. Sauer leg. (MZSP).

Discussão. E. basalis distingue-se das espécies precedentes pela ausência de faixa de pubescência branca no meio dos élitros.

\section{Euestola lineata sp.n.}

Fig. 7

Tegumento castanho-avermelhado. Cabeça grosseiramente pontuada com pubescência amarelada, densa, entre os pontos. Lobos oculares inferiores com o triplo do comprimento das genas; lobos oculares superiores com seis fileiras de omatídios, mais próximos entre si do que a largura de um lobo (macho) ou tão distantes entre si quanto a largura de um lobo (fêmea). Antenas quase tão longas quanto o corpo. Escapo com pubescência amarelada salpicada por pontos glabros, profundos. Tegumento dos flagelômeros castanho-avermelhado com a seguintes regiões de tegumento branco-amarelado: dois terços basais de III, V, VII e IX; metade basal do IV; região apical de XI. Espículo lateral do protórax diminuto, situado ao nível do meio. Pronoto convexo, levemente deprimido transversalmente na base; pontuação densa, profunda, entremeada por pubescência amarelada, mais 
concentrada na região centro-basal e nos lados ao nível dos espículos. Élitros sem crista centro-basal, com leve depressão dorsal ao lado da sutura na metade anterior; pontuação grossa, densa na metade basal e mais esparsa e enfileirada na metade apical; pubescência rala na metade basal e concentrada em faixas entre as fileiras de pontos na metade apical. Face ventral e pernas grosseiramente pontuadas, pontos entremeados por pubescência amarelada. Metatarsômero $\mathrm{V}$ tão longo quanto o I.

Dimensões em milímetros, respectivamente macho/fêmea. Comprimento total, 6,3-8,0/7,8-8,4; comprimento do protórax, 1,4-1,6/1,6-1,7; maior largura do protórax, 1,5-2,2/2,1-2,2; comprimento do élitro, 4,5- 6,1/5,6-6,2; largura umeral, 2,4-3,7/3,0-3,1.

Material- tipo. Holótipo fêmea. BRASIL, Espirito Santo: Linhares, X.1972, P.C. Elias leg. (MZSP). Parátipos: 8 machos, fêmea, mesmos dados do holótipo; 2 machos, fêmea, mesma procedência e coletor, XI.1972 (1 macho, MCNZ; 1 macho, MNRJ).

Discussão. Pela ausência de faixa de pubescência branca nos élitros, $E$. lineata assemelha-se mais a $E$. basalis. Difere: pela pubescência da metade apical dos élitros alinhada entre pontos enfileirados; pelo escapo densa e profundamente pontuado; pelo metatarsômero $\mathrm{V}$ tão longo quanto o I.

\section{Chave para as espécies de Euestola}

1. Élitros com faixa subtransversal de pubescência branca situada no meio . . . . 2 - Élitros sem faixa de pubescência branca . . . . . . . . . . . . . . . 3

2(1). Pronoto com gibosidade centro-posterior; élitros sem crista-centro basal, o terço anterior muito densamente pontuado, região entre pontos glabra. Brasil (Goiás, Mato Grosso do Sul) ................... bidensepunctata

- Pronoto regularmente convexo; élitros com crista centro-basal, o terço anterior densamente pontuado, região entre pontos pubescente. Brasil (São Paulo a Santa Catarina) ............................. fasciata

3(1). Pubescência da metade apical dos élitros organizada em fileiras longitudinais entre os pontos também enfileirados; escapo com pontos grossos; metatarsômero V tão longo quanto o I. Brasil (Espírito Santo) . . . . . . . lineata

- Metade apical dos élitros com pontos não organizados em fileiras e marmorada de pubescência amarelada; escapo finamente pontuado; metatarsômero $\mathrm{V}$ mais longo do que o I. Brasil (Minas Gerais) .............. basalis

\section{Pseudestola Breuning, 1940}

Pseudestola Breuning, 1940: 181. - Monné, 1994: 51 (cat.).

Espécie-tipo, Pseudestola densepunctata Breuning, 1940 (monotipia).

Todo o corpo e apêndices destituídos de setas. Fronte transversal. Olhos grosseiramente granulados. Lobos oculares inferiores com o triplo do comprimento da gena; lobos oculares superiores com 5 fileiras de omatídios, tão distantes entre si quanto a largura de um lobo. Antenas aproximadamente tão longas quanto o 
corpo, com tegumento bicolor. Escapo, antenômeros III e IV com comprimentos subiguais. Protórax apenas mais largo do que longo; espículo lateral situado ao nível do terço posterior. Pronoto regularmente convexo, sem gibosidades. Prosterno muito curto. Élitros uniforme e densamente pontuados em toda a superfície; extremidades arredondadas em conjunto. Fêmures pedunculados e clavados. Mesotíbias com sulco profundo no terço apical.

\section{Pseudestola densepunctata Breuning, 1940}

Fig. 9

Pseudestola densepunctata Breuning, 1940: 182; Monné, 1994: 51 (cat.).

Tegumento vermelho-acastanhado. Flagelômeros castanhos com tegumento branco-amarelado em: dois terços basais de III e IV; inteiramente, exceto o ápice, em VI, VIII e X. Todo o corpo com pubescência amarelada, esparsa, sem setas. Pronoto e élitros densa e uniformemente pontuados.

Dimensões em milímetros. Comprimento total, 4,6; comprimento do protórax, 1,0; maior largura do protórax, 1,3; comprimento do élitro, 3,4; largura umeral, 1,6 .

Material examinado. BRASIL, Rio de Janeiro: Rio de Janeiro, fêmea, XI, Acc. $n^{\circ} 2966(\mathrm{CMNH})$.

AGRADECIMENTOS. A Renato C. Marinoni pelo empréstimo dos diapositivos dos tipos feitos por J.S. Moure; a Tiago C. Ramos pelo auxílio na execução das fotografias.

\section{REFERÊNCIAS BIBLIOGRÁFICAS}

BREUNING, S. 1940. Novae species Cerambycidarum. VIII. Folia zool. hydrobiol., Riga, 10: 115-214.

12: $12-66$. 1-210.

MonNÉ, M.A. 1994. Catalogue of the Cerambycidae (Coleoptera) of the

Westerm Hemisphere, Part XVI. São Paulo, Sociedade Brasileira de Entomologia, 98p. 